\title{
A new species of Heydenia Förster (Hymenoptera: Chalcidoidea: Pteromalidae) from Sri Lanka, with a key to species of the Indian subcontinent
}

\author{
P.M. Sureshan \\ Zoological Survey of India, Gangetic Plains Regional Station, Rajendra Nagar, Patna, Bihar 800016, India \\ Email: samanyu2003@yahoo.com
}

Date of online publication 26 February 2009 ISSN 0974-7907 (online) | 0974-7893 (print)

Editor: T.C. Narendran

\section{Manuscript details:}

Ms \# 01972

Received 31 March 2008

Final revised received 27 August 2008

Finally accepted 07 September 2008

Citation: Sureshan, P.M. (2009). A new species of Heydenia Förster (Hymenoptera: Chalcidoidea: Pteromalidae) from Sri Lanka, with a key to species of the Indian subcontinent. Journal of Threatened Taxa 1(2): 114-116.

Copyright: ( P P.M. Sureshan 2008. Creative Commons Attribution 3.0 Unported License. JoTT allows unrestricted use of this article in any medium for non-profit purposes, reproduction and distribution by providing adequate credit to the authors and the source of publication.

Author Details: P.M. SURESHAN is currently Officer-in-Charge of Zoological Survey of India, Gangetic Plains Regional Station, Patna, Bihar. He is actively pursuing research on biosystematics of parasitic Hymenoptera (Chalcidoidea) for the last two decades. He has also carried out taxonomic research on animal groups like Mantodea, Scolopendromorpha and Scorpiones in collaboration with experts in the field.

Acknowledgements: I am grateful to the Director, Zoological Survey of India, Kolkatta for providing facilities and encouragement. I am also grateful to Dr. Steven L. Heydon, Bohart Museum, University of California, USA for arranging the loan of specimens for my study and Dr. Dr. Gary A.P. Gibson, Agriculture and Agri-Food Canada, Ontario, Canada for providing copy of his work on the Phylogeny of world Cleonyminae and other relevant literature.

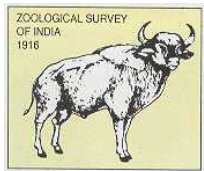

OPEN ACCESS | FREE DOWNLOAD
Abstract: A new species of the pteromalid genus, Heydenia Förster, H. gibsoni, is described from Sri Lanka and a key to species of the Indian subcontinent provided.

Keywords: Chalcidoidea, Heydenia, Hymenoptera, key, new species, Pteromalidae, Sri Lanka.

Abbreviations: F1-F7 - Funicular segments first to seventh; OOL - Ocello-ocular distance; POL - Post-ocellar distance; SMV - Submarginl vein; MV - Marginal vein; PMV - Postmarginal vein; STV - Stigmal vien; T1-T4 - Tergites one to four of gaster.

\section{INTRODUCTION}

The pteromalid genus, Heydenia Förster belongs to the subfamily Cleonyminae. This genus is nearly cosmopolitan in distribution, and is represented by 19 described and many undescribed species in the world (Gibson 2003; Noyes 2007; Bouček 1988). Heydenia species are parasitoids of the larvae and pupae of wood boring beetles of the families Buprestidae, Cerambycidae, Curculionidae and Scolytidae and are often found on the trunks and branches of dying trees attacked by these beetles. From the Indian subcontinent the genus is represented by two species viz. H. tuberculata Sureshan from Karnataka and H.indica Narendran from Kashmir and an undescribed species from Sri Lanka (Sureshan 2000; Narendran et al. 2001; Bouček et al. 1979). In this paper one new species of Heydenia is described from Sri Lanka based on two specimens in the collections of the Bohart Museum of Entomology, University of California, Davis, USA, which are on loan to me by the kind courtesy of Dr. Steven Heydon. A key to the species of Heydenia of the Indian subcontinent is also provided here. The type specimens are deposited in the Bohart Museum of Entomology, University of California, Davis, USA.

Heydenia gibsoni sp. nov.

(Figs.1-3)

\section{Material examined}

Holotype: Female, 23-30.viii.1999, 0 $7^{\circ} 13^{\prime} \mathrm{N} \& 08^{\circ} 57^{\prime} \mathrm{E}$, Rantembe Sanctuary, Randenigala Viet., Kandy district, Central Province, Sri Lanka, coll. M.T.M. \& J. Washbauer, Bohart Museum of Entomology A-1172.

Paratype: Male same data as that of holotype.

\section{Etymology}

Named in honour of Dr. Gary A.P. Gibson, Agriculture and Agri-Food Canada, Ontario, Canada for his remarkable contributions to the phylogenetics of the world Cleonyminae.

\section{Diagnostic characters}

Female: Length. $3 \mathrm{~mm}$ (excluding ovipositor), ovipositor $1.2 \mathrm{~mm}$. Head and thorax metallic greenish-blue with golden brassy reflection on face, sides of thorax, mesoscutum and scutellum (completely) and head dorsally (head more darker), mainly brownish, with bluish-violet reflections on lower face; lower face and parascrobal area with silvery white setae; metanotum and propodeum bluish-violet; antennae dark brown except scape testaceous basally; mandibles blackish-brown; tegulae brown; wings hyaline, veins pale brown, one broad dark brown infumation on stigmal area and one small brown spot at parastigma and two brownish-black tuft of setae one at parastigma and other at base of MV, pubescence brown; legs yellowish-brown, tarsi whitish, coxae laterally with metallic blue reflections, prominent on fore and hind coxae; gaster blackish-brown with slight 
metallic bluish reflection dorsobasally, petiole and subbasal patch on T1 testaceous, ovipositor sheaths brown, ovipositor testaceous.

Head: Densely reticulate on lower face almost up to $3 / 4$ area; rest of face finely reticulate upto ocelli, vertex and rest of head moderately reticulate except on area below lateral margin of eye shiny which extends up to vertex. Malar grooves distinct. Head in front view slightly wider than long (1.03x); eye length $1.53 \mathrm{x}$ width (in profile); malar space length $0.5 \mathrm{x}$ eye length (in profile); gena posteriorly not carinate; toruli separated by a distance $0.6 \mathrm{x}$ that of distance of it from mouth margin; both mandible with three teeth. In dorsal view head width $1.5 \mathrm{x}$ length, temple narrow, about $0.2 \mathrm{x}$ eye length, vertex $0.4 \mathrm{x}$ head width; ocelli in an equilateral triangle; POL 2x OOL. Antennae (Fig. 1) inserted below middle of face and slightly below lower margin of eyes, formula 11173; scape expanded towards tip, curved, just short of reaching front ocellus, length 084x eye length; pedicel shorter than F1; anellus transverse; pedicellus plus flagellum $1.32 \mathrm{x}$ head width; relative lengths of pedicel 4, F1 5.5, F2 5, F3 5, F4 4.5, F5 4, F6 3, F7 3; funicular segments gradually decreasing in length and slightly widening towards tip; club acuminate, almost as long as 3 preceding segments combined, each funicular segments with two rows of long sensillae, area of micropilosity restricted to the last segment of club.

Thorax: Reticulate punctate, pubescence less dense, lateral panel of pronotum shiny on lower and upper halves. Pronotum transverse, collar horizontal with lateral panel bent about $90^{\circ}$ in relation to dorsal surface. Mesoscutum width $1.52 \mathrm{x}$ median length, notauli almost complete. Scutellum convex, reticulation closer, evenly curved posteriorly down to dorsellum without marginal rim, medially as long as mesoscutum; axilla reticulate, moderately advanced, axillular carina indicated, axillula almost shiny; scutoscutellar sulcus with a tuft of white setae, frenal line indicated laterally; dorsellum broad, shiny, extending slightly over scutellum. Propodeum (Fig. 3) medially $1.81 \mathrm{x}$ as broad as long with distinct median carina and plicae which enclose a well defined hexagonal area, posterior margin deeply emarginated, almost shiny centrally and finely reticulate laterally; spiracles round, away from hind margin of metanotum by a distance more than its diameter, post spiracular sulcus not indicated, callus and hind margin of propodeum with translucent setae. Prepectus broad, triangular, striate reticulate with dense setae, anterior margin longer than tegula. Mesopleuron densely reticulate except for a small smooth area below wings. Metapleuron reticulate. Mesopleuron and metapleuron with dense slivery white hairs on the lower half. Forewing (Fig. 2) length $2.7 \mathrm{x}$ width, membrane with reduced discal ciliation, almost bare basally, marginal fringe very small, PMV distinctly shorter than MV and slightly longer than STV. Relative lengths: SMV 38, MV 15.5, PMV 6.5, STV 4.5. Fore femora moderately enlarged with a row of spines on the ventral margin, fore tibia with a row of spines in the ventral and apical margins.

Gaster: (Fig.3) Petiole distinct, wider than long, widened posteriorly, gaster (including petiole and excluding ovipositor) $1.1 \mathrm{x}$ as long as thorax, T1 constricted in the form of a basal stalk, posterior margin of $\mathrm{T} 1$ and $\mathrm{T} 2$ distinctly incised in the middle, T3 onwards finely reticulate, hypopygium reaching hind margin of $\mathrm{T} 4$.

Male: Length: $2.2 \mathrm{~mm}$. Closely resembles female but differs
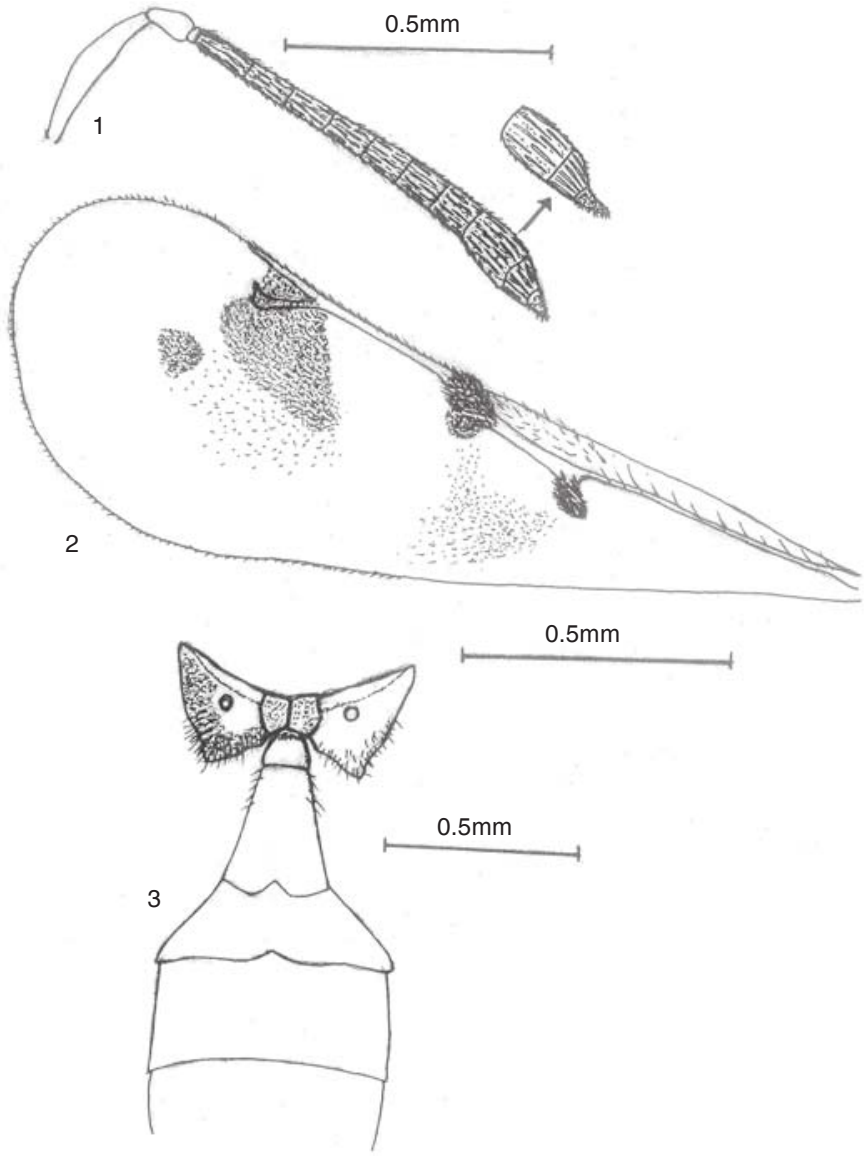

Figures 1-3. Heydenia gibsoni sp. nov. (Female) 1 - antenna; 2 - forewing; 3 - propodeum and basal part of gaster dorsal view

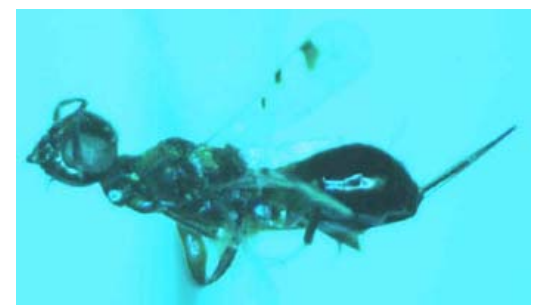

Image 1. Heydenia gibsoni sp. nov. (Female)

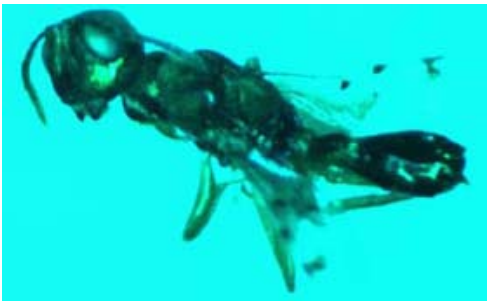

Image 2. Heydenia gibsoni sp. nov. (Male)

as follows: legs including coxae brownish-yellow with a small metallic blue patch laterally only on hind coxae, antennae with pubescence denser, gaster shorter, forewing with infumation below STV small and no infumation below base of MV.

Remarks: Among the Indian species, the new species resembles H.indica Narendran in general morphology especially in the nature of antenna, forewing, fore femur etc., 


\section{Key to Heydenia species of Indian subcontinent}

1. Propodeum with a ' $Y$ ' shaped median carina with an anteriorly curved sharp tooth, axillae smooth and shiny, India: Karnatkaka

- $\quad$ Propodeum different, without tooth or tubercle on the median carina; axillae reticulate.

2. Ovipositor sheath a little over $0.65 x$ length of hind tibia (in side view), gaster subsessile, petiole very short, India: Kashmir H. indica Narendran

- $\quad$ Ovipositor sheath long, 1.56x as long as hind tibia, gaster with distinct petiole Sri Lanka H. gibsoni sp. nov.

but differs in having gaster with a distinct petiole, long ovipositor sheaths (1.56x as long as hind tibia in side view), $\mathrm{T} 1$ and $\mathrm{T} 2$ distinctly incised in the posterior margin, forewing with longer marginal vein $(2.3 \mathrm{x}$ PMV) with small brown infumation below base of $\mathrm{MV}$, and different propodeum (in H.indica gaster subsessile with very short petiole, ovipositor sheaths a little over $0.65 \mathrm{x}$ hind tibia (in side view), $\mathrm{T} 1$ and $\mathrm{T} 2$ very slightly sinuate along posterior margin, forewing with MV a little less than 2x PMV and without any infumation below base of MV and different propodeum). In having a longer ovipositor (longer than the hind tibia) it also resembles H.trinodis Boucek and H. burgeoni (Risbec). However, both these species differ from the new species in general morphology. The new species fits into the couplet 3 of the key to IndoAustralian species of Heydenia by Narendran et al. 2001 but can be segregated from other species of the key $H$. indica (Narendran), H. longicollis (Cameron) and H. cristatipennis (Girault) in having a long ovipositor sheath, length $1.4 \mathrm{x}$ as long as hind tibia in dorsal view and petiole clearly visible from dorsal side which is widened posteriorly and width $1.5 \mathrm{x}$ length.

\section{References}

Bouček, Z. ( 1988). Australasian Chalcidoidea (Hymenoptera): CAB International, Wallingford, 832pp.

Boucek, Z., B.R.S. Rao \& S.I. Farooqi (1979). A preliminary review of Pteromalidae (Hymenoptera) of India and adjacent countries. Oriental Insects 12(4): 433-468.

Gibson, G.A.P. (2003). Phylogenetics and classification of Cleonyminae (Hymenoptera: Chalcidoidea: Pteromalidae). Memoirs on Entomology, International. 16: 1-339.

Narendran, T.C., A.A. Buhroo \& M.Z. Chisti (2001). Taxonomic studies on four new species of Chalcidoidea (Hymenoptera) of Economic importance from Kashmir, India. Entomon 26(2): 147-159.

Noyes, J.S. (2007). Universal Chalcidoidea database. http://www. nhm.ac.uk/jdsml/research-curation/projects/ chalcidoids. Last updated May 2008

Sureshan, P.M. (2000). A new species of Heydenia Forster (Hymenoptera: Pteromalidae) from India. Zoos' Print Journal 15(2): 197-198. 